\title{
Assessment of Pharmacy Students' Satisfaction towards Pharmacotherapy Lectures Delivered at the University of Gondar, Gondar, Ethiopia
}

\author{
Malede Berihun Yismaw ${ }^{10},{ }^{1}$ Zelalem Tilahun Tesfaye, ${ }^{2}$ \\ and Akshaya Srikanth Bhagavathula ${ }^{3}{ }^{3}$ \\ ${ }^{1}$ Department of Pharmacy, College of Medicine and Health Sciences, Bahir Dar University, Bahir Dar, Ethiopia \\ ${ }^{2}$ Department of Pharmacology and Clinical Pharmacy, School of Pharmacy, College of Health Sciences, Addis Ababa University, \\ Addis Ababa, Ethiopia \\ ${ }^{3}$ Internal Medicine, United Arab Emirates University, Al Ain, UAE
}

Correspondence should be addressed to Malede Berihun Yismaw; malepharm@gmail.com

Received 1 July 2021; Accepted 18 August 2021; Published 25 August 2021

Academic Editor: Connie M. Wiskin

Copyright (C) 2021 Malede Berihun Yismaw et al. This is an open access article distributed under the Creative Commons Attribution License, which permits unrestricted use, distribution, and reproduction in any medium, provided the original work is properly cited.

\begin{abstract}
Background. Quality healthcare can be assured by fostering quality teaching-learning process. Students are well-equipped to judge the quality of the teaching-learning process. Consequently, students' satisfaction should be considered for the improvement of quality teaching. Objective. The study aimed to explore how far the University of Gondar (UoG) provides quality pharmacy education based on the perspective of students using the validated Instructional Skills Questionnaire (ISQ). Methods. A crosssectional survey was conducted on May 2018 GC on 105 pharmacy students at the University of Gondar, Northern Ethiopia. Data were collected using the suspected demographic information and the validated Instructional Skills Questionnaire (ISQ). Data were entered into IBM SPSS Statistics ${ }^{\circledR}$ version 25, and the results of the analysis were described using descriptive and inferential statistics. A letter of ethical approval was obtained from the ethical review board of the University of Gondar prior to data collection. Results. More than half (58.6\%) of the participants were female, and $85.1 \%$ of the subjects aged between 21 and 25 years. The highest students' satisfaction was in the ISQ dimension of explication (58.03\%) followed by instruction (56.13\%) and comprehension (52.78). Student's T-test showed that extension (night-shift) students have a higher average satisfaction score $(3.54 \pm 0.34)$ compared to regular (day-shift) students $(3.31 \pm 0.41)(t(103)=2.422, p=0.017)$. Similarly, fourth-year students showed higher average satisfaction $(3.54 \pm 0.33)$ as compared to fifth-year students $(3.28 \pm 0.42)(t(103)=3.41, p=0.002)$. Conclusion. In the present study, a higher students' satisfaction was obtained about explication (58.03\%) among seven ISQ dimensions, while students' satisfaction related to activation was minimal (49\%). Students' satisfaction related to the learning outcome was found to be relatively high $(67.23 \%)$. The study also showed that there is a significant difference in students' satisfaction within the different study programs and years of study. Hence, the instructors should work to improve students' satisfaction, thereby increasing the number of qualified professionals in the market.
\end{abstract}

\section{Introduction}

Quality healthcare is one of the most important factors in how individuals perceive their quality of life. In most countries, alongside the economy, it is the major political issue. In some countries, the healthcare delivery organization is a part of the national identity $[1,2]$.
In order to assure quality healthcare, there should be quality teaching. Educational system itself, class community, teaching methods, online learning, student community, student engagement, staff development, curriculum development, educational policy, local or global changes of the environment etc. are complex systems that might affect teaching-learning quality [3]. 
Students' changing expectations of higher education and the consequences of mismatches with reality lead to the question whether students are in the best position to judge aspects of quality, although students are well-equipped to judge certain aspects of the quality of the teaching-learning process [4].

The survey tool designed to assess quality of teaching should be precise and clear so as to avoid confusions and reduce participants' fatigue during data collection [5].

The situation has alerted and called the attention of researchers to bring to light the situation on the ground in universities by assessing the satisfaction of students [6].

The American College of Clinical Pharmacy (ACCP) believes that a consistent level of high-quality outcomefocused experiential education should be established. This education must encompass the knowledge, skills, and attitudes necessary for graduates to enter pharmacy practice in any setting. Schools of pharmacy should be accountable for the educational outcomes of their graduates to deliver pharmaceutical care [7]. Pharmaceutical care is a patientcentered practice that results in positive pharmacotherapeutic outcomes for patients through identification, resolution, and prevention of drug-related problems, as well as encouraging proper use of medications. The goal of pharmaceutical care is to optimize the patient's healthrelated quality of life [8]. By integrating the knowledge and skills, students will be able to acquire abilities in therapeutics when they become pharmacists $[9,10]$. Emphasis placed on accountability for educational outcomes is vital to a superior education and in providing citizens with the highest quality care. In order to assure this, faculty members should evaluate whether students have achieved their attitudinal, behavioral, and knowledge learning outcomes [10].

Therefore, the present study aimed to explore how far the University of Gondar (UoG) provides quality pharmacy education based on the perspective of students using the validated Instructional Skills Questionnaire (ISQ) [11].

\section{Main Text}

2.1. Methods. The study was conducted during the month of May 2018 and included students from School of Pharmacy, University of Gondar. One hundred five pharmacy students were included. Students' participation was voluntary, but all of them participated. The paper-based questionnaire was used. Pharmacotherapy lectures are given in 4 semesters consequently as courses Pharmacotherapy I-IV, and assessment was made after immediate completion of the lectures.

The survey instrument was generated using the sociodemographic information and the validated ISQ. The ISQ consisted of seven dimensions of instructors' instructional skills and three student (self-perceived) learning outcomes. The seven dimensions include structure, explication, stimulation, validation, instruction, comprehension, and activation of the learning processes. Each of these assessment items provides four statements, except the student learning outcomes where only three statements were provided. After a pilot study, changes were made to improve the assessment statements.

The ISQ employs a five-point Likert tool, in which the participant's responses were given values such that one is given for "strongly disagree," two for "disagree," three for "neither agree nor disagree" four for "agree," and "five" for "strongly agree" for positively worded statements and the reverse for negatively worded questions. Analysis was done using IBM SPSS Statistics ${ }^{\circledR}$ version 25 with descriptive and inferential statistics.

\section{Results}

In the present study, more than half of participants were female. Only 74 (70.5\%) participants disclosed their age. The age ranged from 21 to 52, and the majority of the participants were in the age range of $21-25(85.1 \%)$. Regarding the study program, the majority $(78.1 \%)$ of the study subjects were enrolled in the regular program. The study was conducted on $4^{\text {th }}$ - and $5^{\text {th }}$-year students since others did not finish the pharmacotherapy course as per the university curriculum. Fifth-year students represent $69.6 \%$ of the participants, and more than three-fourth of them were urban residents (Table 1).

Table 2 summarizes the 31 statements that elicit students' level of satisfaction using the seven ISQ dimensions on teaching behavior and student learning outcomes at the UoG Pharmacy School. The 7 ISQ dimensions include lecture structure, explication, stimulation, validation, instruction, comprehension, and activation, whereas student learning outcomes measure cognitive, affective, and regulative outcomes.

The level of satisfaction with regard to lecture structure was $52.08 \%$. Satisfaction was positive towards the clarity of the lecture structure $(M \pm \mathrm{SD}=3.49 \pm 1.03)$ and the instructors' ability to give clear summaries $(M \pm \mathrm{SD}=$ $3.48 \pm 1.03)$.

About $58.03 \%$ of the participants were satisfied with regard to explication. Majority of the students were satisfied with the subject matter explanation and clarity $(M \pm \mathrm{SD}=3.61 \pm 0.98)$ and the ability of instructors to give clarifying examples $(M \pm \mathrm{SD}=3.59 \pm 1.01)$.

Around half $(49.18 \%)$ of the students were satisfied regarding stimulation. Students were satisfied with regard to instructors' interest on the subject matter $(M \pm \mathrm{SD}=$ $3.48 \pm 1.03)$ while disagreeing on the lectures being boring $(M \pm \mathrm{SD}=3.40 \pm 1.15)$.

With respect to validation, $50.18 \%$ of the students were satisfied. They are more satisfied that instructors indicate the relevance of the subject matter $(M \pm \mathrm{SD}=3.86 \pm 4.01)$ followed by the instructors showing the importance of the subject matter $(M \pm \mathrm{SD}=3.56 \pm 1.11)$.

Regarding the instruction, students' satisfaction was $56.13 \%$. The result showed that the instructors indicate which parts of the subject matter are essential $(M \pm \mathrm{SD}=3.58 \pm 1.11)$ and it is clear what the instructors require of students $(M \pm \mathrm{SD}=3.45 \pm 1.05)$.

Slightly more than half $(52.78 \%)$ of the participants were satisfied with respect to comprehension. Students showed 
TABle 1: Demographic characteristics of the patients.

\begin{tabular}{lcc}
\hline Variable & Category & Number $(\%)$ \\
\hline \multirow{2}{*}{ Age } & $21-25$ years & $63(85.1)$ \\
& $8(10.8)$ & $3(4.1)$ \\
\hline \multirow{2}{*}{ Sex } & $26-30$ years & $54(51.4)$ \\
& $>30$ years & $51(58.6)$ \\
\hline \multirow{2}{*}{ Study program } & Male & $82(78.1)$ \\
& Female & $23(21.9)$ \\
\multirow{2}{*}{ Year of study } & Regular & $33(31.4)$ \\
& Extension & $72(69.6)$ \\
\multirow{2}{*}{ Hometown } & $4^{\text {th }}$ year & $77(76.2)$ \\
& $5^{\text {th }}$ year & $24(23.8)$ \\
\hline
\end{tabular}

TABle 2: Attainment of satisfaction levels in each characteristic $(N=105)$.

\begin{tabular}{|c|c|c|c|c|c|c|c|c|}
\hline SN & Characteristics & $\begin{array}{l}\text { Strongly } \\
\text { agree (5) } \\
n(\%)\end{array}$ & $\begin{array}{l}\text { Agree } \\
\quad(4) \\
n(\%)\end{array}$ & $\begin{array}{c}\text { Neither agree } \\
\text { nor disagree } \\
(3) \\
n(\%)\end{array}$ & $\begin{array}{l}\text { Disagree } \\
\quad(2) \\
n(\%)\end{array}$ & $\begin{array}{c}\text { Strongly } \\
\text { disagree (1) } \\
n(\%)\end{array}$ & $\begin{array}{l}{ }^{*} \text { Mean } \pm \text { standard } \\
\text { deviation }\end{array}$ & $\begin{array}{c}\text { Overall } \\
\text { satisfaction (\%) }\end{array}$ \\
\hline \multicolumn{9}{|c|}{ Structure } \\
\hline $\mathrm{S} 1$ & $\begin{array}{c}\text { The lectures have a clear } \\
\text { structure }\end{array}$ & $11(10.5)$ & $\begin{array}{c}56 \\
(53.3)\end{array}$ & $15(14.3)$ & $19(18.1)$ & $4(3.8)$ & $3.49 \pm 1.03$ & \multirow{4}{*}{52.08} \\
\hline S2 & $\begin{array}{c}\text { The instructors give clear } \\
\text { summaries }\end{array}$ & $10(9.5)$ & $\begin{array}{c}57 \\
(54.3)\end{array}$ & $16(15.2)$ & $17(16.2)$ & $5(4.8)$ & $3.48 \pm 1.03$ & \\
\hline S3 & $\begin{array}{l}\text { The subject matter is presented } \\
\text { incoherently* }\end{array}$ & $10(9.7)$ & $\begin{array}{c}38 \\
(36.9)\end{array}$ & $22(21.4)$ & $25(24.3)$ & $8(7.8)$ & $2.83 \pm 1.14$ & \\
\hline S4 & The lectures are unorganized* & $11(10.7)$ & $\begin{array}{c}19 \\
(18.4)\end{array}$ & $23(22.3)$ & $39(37.9)$ & $11(10.7)$ & $3.19 \pm 1.18$ & \\
\hline \multicolumn{9}{|c|}{ Explication } \\
\hline E1 & $\begin{array}{l}\text { The instructors explain the } \\
\text { subject matter clearly }\end{array}$ & $14(13.5)$ & $\begin{array}{c}55 \\
(52.9)\end{array}$ & $18(17.3)$ & $14(13.5)$ & $3(2.9)$ & $3.61 \pm 0.98$ & \multirow{4}{*}{58.03} \\
\hline E2 & The instructors are unclear* & $6(5.8)$ & $\begin{array}{c}12 \\
(11.5)\end{array}$ & $25(24.0)$ & $45(43.3)$ & $16(15.4)$ & $3.51 \pm 1.07$ & \\
\hline E3 & $\begin{array}{l}\text { The instructors' explanations } \\
\text { are hard to follow* }\end{array}$ & $3(2.9)$ & $\begin{array}{c}11 \\
(10.8)\end{array}$ & $39(38.2)$ & $35(34.3)$ & $14(13.7)$ & $3.45 \pm 0.96$ & \\
\hline $\mathrm{E} 4$ & $\begin{array}{l}\text { The instructors give clarifying } \\
\text { examples }\end{array}$ & $18(17.1)$ & $\begin{array}{c}44 \\
(41.9) \\
\end{array}$ & $29(27.6)$ & $10(9.5)$ & $4(3.8)$ & $3.59 \pm 1.01$ & \\
\hline \multicolumn{9}{|c|}{ Stimulation } \\
\hline S1 & The lectures are boring* & $6(5.7)$ & $\begin{array}{c}20 \\
(19.0)\end{array}$ & $23(21.9)$ & $38(36.2)$ & $18(17.1)$ & $3.40 \pm 1.15$ & \multirow{4}{*}{49.18} \\
\hline S2 & $\begin{array}{c}\text { The instructors enliven the } \\
\text { subject matter }\end{array}$ & $7(7.0)$ & $\begin{array}{c}37 \\
(37.0)\end{array}$ & $39(39.0)$ & $14(14.0)$ & $3(3.0)$ & $3.31 \pm 0.91$ & \\
\hline S3 & $\begin{array}{c}\text { It is hard to stay focused on the } \\
\text { lectures* }\end{array}$ & $4(3.8)$ & $\begin{array}{c}34 \\
(32.7)\end{array}$ & $23(22.1)$ & $36(34.6)$ & $7(6.7)$ & $3.08 \pm 1.05$ & \\
\hline S4 & $\begin{array}{l}\text { The instructors interest you in } \\
\text { the subject matter }\end{array}$ & $12(11.4)$ & $\begin{array}{c}49 \\
(46.7) \\
\end{array}$ & $28(26.7)$ & $9(8.6)$ & $7(6.7)$ & $3.48 \pm 1.03$ & \\
\hline \multicolumn{9}{|c|}{ Validation } \\
\hline V1 & $\begin{array}{l}\text { Little is said about the } \\
\text { application of the subject } \\
\text { matter* }\end{array}$ & $12(11.5)$ & $\begin{array}{c}31 \\
(29.8)\end{array}$ & $20(19.2)$ & $32(30.8)$ & $9(8.7)$ & $2.95 \pm 1.19$ & \multirow{4}{*}{50.18} \\
\hline $\mathrm{V} 2$ & $\begin{array}{l}\text { The instructors indicate the } \\
\text { relevance of the subject matter }\end{array}$ & $11(10.5)$ & $\begin{array}{c}58 \\
(55.2)\end{array}$ & $15(14.3)$ & $13(12.4)$ & $8(7.6)$ & $3.86 \pm 4.01$ & \\
\hline V3 & $\begin{array}{c}\text { The utility of the subject matter } \\
\text { is hardly discussed* }\end{array}$ & $11(10.5)$ & $\begin{array}{c}38 \\
(36.2)\end{array}$ & $25(23.8)$ & $18(17.1)$ & $13(12.4)$ & $2.85 \pm 1.20$ & \\
\hline V4 & $\begin{array}{l}\text { The instructors show why the } \\
\text { subject matter is important }\end{array}$ & $16(15.5)$ & $\begin{array}{c}52 \\
(50.5)\end{array}$ & $17(16.5)$ & $10(9.7)$ & $8(7.8)$ & $3.56 \pm 1.11$ & \\
\hline
\end{tabular}


TABLe 2: Continued.

\begin{tabular}{|c|c|c|c|c|c|c|c|c|}
\hline SN & Characteristics & $\begin{array}{l}\text { Strongly } \\
\text { agree (5) } \\
n(\%)\end{array}$ & $\begin{array}{l}\text { Agree } \\
\quad(4) \\
n(\%)\end{array}$ & $\begin{array}{c}\text { Neither agree } \\
\text { nor disagree } \\
(3) \\
n(\%) \\
\end{array}$ & $\begin{array}{l}\text { Disagree } \\
\quad(2) \\
n(\%)\end{array}$ & $\begin{array}{c}\text { Strongly } \\
\text { disagree (1) } \\
n(\%)\end{array}$ & $\begin{array}{c}{ }^{*} \text { Mean } \pm \text { standard } \\
\text { deviation }\end{array}$ & $\begin{array}{c}\text { Overall } \\
\text { satisfaction (\%) }\end{array}$ \\
\hline \multicolumn{9}{|c|}{ Instruction } \\
\hline I1 & $\begin{array}{l}\text { The instructors are unclear } \\
\text { about which aspects of the } \\
\text { subject matter are important* }\end{array}$ & $5(4.8)$ & $\begin{array}{c}24 \\
(23.1)\end{array}$ & $23(22.1)$ & $37(35.6)$ & $15(14.4)$ & $3.32 \pm 1.13$ & \multirow{4}{*}{56.13} \\
\hline $\mathrm{I} 2$ & $\begin{array}{l}\text { It is often unclear what the } \\
\text { main and side issues are }\end{array}$ & $6(5.8)$ & $\begin{array}{c}25 \\
(24.3)\end{array}$ & $20(19.4)$ & $37(35.9)$ & $15(14.6)$ & $3.29 \pm 1.16$ & \\
\hline I3 & $\begin{array}{l}\text { It is clear what the instructors } \\
\text { require of me }\end{array}$ & $12(11.5)$ & $\begin{array}{c}49 \\
(47.1)\end{array}$ & $23(22.1)$ & $14(13.5)$ & $6(5.8)$ & $3.45 \pm 1.05$ & \\
\hline I4 & $\begin{array}{c}\text { The instructors indicate which } \\
\text { parts of the subject matter are } \\
\text { essential }\end{array}$ & $18(17.3)$ & $\begin{array}{c}50 \\
(48.1)\end{array}$ & $17(16.3)$ & $12(11.5)$ & $7(6.7)$ & $3.58 \pm 1.11$ & \\
\hline \multicolumn{9}{|c|}{ Comprehension } \\
\hline $\mathrm{C} 1$ & $\begin{array}{c}\text { The instructors provide } \\
\text { insufficient occasion to ask } \\
\text { questions* }\end{array}$ & $4(3.8)$ & $\begin{array}{c}27 \\
(26.0)\end{array}$ & $28(26.9)$ & $33(31.7)$ & $12(11.5)$ & $3.21 \pm 1.08$ & \multirow{4}{*}{52.78} \\
\hline $\mathrm{C} 2$ & $\begin{array}{l}\text { The instructors encourage } \\
\text { students to ask questions about } \\
\text { the subject matter }\end{array}$ & $22(21.0)$ & $\begin{array}{c}54 \\
(51.4)\end{array}$ & $19(18.1)$ & $7(6.7)$ & $3(2.9)$ & $3.81 \pm 0.94$ & \\
\hline C3 & $\begin{array}{c}\text { The instructors check whether } \\
\text { students understand the subject } \\
\text { matter }\end{array}$ & $16(15.2)$ & $\begin{array}{c}51 \\
(48.6)\end{array}$ & $23(21.9)$ & $9(8.6)$ & $6(5.7)$ & $3.59 \pm 1.04$ & \\
\hline $\mathrm{C} 4$ & $\begin{array}{l}\text { The instructors hardly address } \\
\text { the students' comments* }\end{array}$ & $11(10.6)$ & $\begin{array}{c}32 \\
(30.8)\end{array}$ & $28(26.9)$ & $20(19.2)$ & $13(12.5)$ & $2.92 \pm 1.20$ & \\
\hline \multicolumn{9}{|c|}{ Activation } \\
\hline A1 & $\begin{array}{l}\text { Students are encouraged to } \\
\text { think along during the lecture }\end{array}$ & $8(7.6)$ & $\begin{array}{c}55 \\
(52.4)\end{array}$ & $19(18.1)$ & $18(17.1)$ & $5(4.8)$ & $3.41 \pm 1.02$ & \multirow{4}{*}{49} \\
\hline $\mathrm{A} 2$ & $\begin{array}{l}\text { The instructors provide little } \\
\text { opportunity for discussions* }\end{array}$ & $8(7.6)$ & $\begin{array}{c}32 \\
(30.5)\end{array}$ & $23(21.9)$ & $31(29.5)$ & $11(10.5)$ & $3.05 \pm 1.16$ & \\
\hline A3 & $\begin{array}{l}\text { During the lectures there is } \\
\text { hardly any occasion to discuss } \\
\text { the subject matter* }\end{array}$ & $6(5.7)$ & $\begin{array}{c}38 \\
(36.2)\end{array}$ & $32(30.5)$ & $22(21.0)$ & $7(6.7)$ & $2.87 \pm 1.03$ & \\
\hline $\mathrm{A} 4$ & $\begin{array}{l}\text { The instructors involve } \\
\text { students in the lecture }\end{array}$ & $12(11.9)$ & $\begin{array}{c}57 \\
(56.4) \\
\end{array}$ & $20(19.8)$ & $6(5.9)$ & $6(5.9)$ & $3.62 \pm 0.98$ & \\
\hline \multicolumn{9}{|c|}{ Student learning outcomes } \\
\hline $\mathrm{O} 1$ & $\begin{array}{l}\text { Cognition: I learned a lot from } \\
\text { the lectures }\end{array}$ & $21(20.0)$ & $\begin{array}{c}55 \\
(52.4)\end{array}$ & $15(14.3)$ & $7(6.7)$ & $7(6.7)$ & $3.72 \pm 1.07$ & \multirow{3}{*}{67.23} \\
\hline $\mathrm{O} 2$ & $\begin{array}{l}\text { Affection: because of the } \\
\text { lectures, I want to learn more } \\
\text { about the subject matter }\end{array}$ & $22(21.0)$ & $\begin{array}{c}44 \\
(41.9)\end{array}$ & $24(22.9)$ & $7(6.7)$ & $8(7.6)$ & $3.62 \pm 1.12$ & \\
\hline $\mathrm{O} 3$ & $\begin{array}{l}\text { Regulation: because of the } \\
\text { lectures, I now know what I } \\
\text { have yet to study }\end{array}$ & $27(26.0)$ & $\begin{array}{c}42 \\
(40.4)\end{array}$ & $22(21.2)$ & $7(6.7)$ & $6(5.8)$ & $3.74 \pm 1.10$ & \\
\hline
\end{tabular}

$*$ Note that negative statements are given reverse values such that strongly agree $(\mathrm{SA})=1$, agree $(\mathrm{A})=2$, neutral $=3$, disagree $(\mathrm{DA})=4$, and strongly disagree $(\mathrm{SD})=5$.

more satisfaction rate regarding instructors' encouragement on students to ask questions about the subject matter $(M \pm \mathrm{SD}=3.81 \pm 0.94)$ followed by checking whether students understand the subject matter $(M \pm \mathrm{SD}=3.59 \pm 1.04)$.

A lower overall satisfaction (48.53\%) was obtained with activation parameters. Students appeared to be more dissatisfied on the statement which says "during the lectures there is hardly any occasion to discuss the subject matter" $(M \pm \mathrm{SD}=2.87 \pm 1.03)$.

On the contrary, the study result showed a great student satisfaction rate $(67.23 \%)$ regarding students' learning outcomes as compared to the other characteristics. The cognition, affection, and regulation outcomes were assessed, and the majority of students were satisfied in these three statements. The overall students' satisfaction in each subgroup assessment tool is also summarized in Figure 1.

Student's $t$-test was performed to analyze the difference in satisfaction across different groups of students. Accordingly, extension (night-shift) students showed higher average satisfaction score $(3.54 \pm 0.34)$ compared to regular (day-shift) students $(3.31 \pm 0.41) \quad(t \quad(103)=2.422$, $p=0.017)$. Similarly, fourth-year students showed higher 


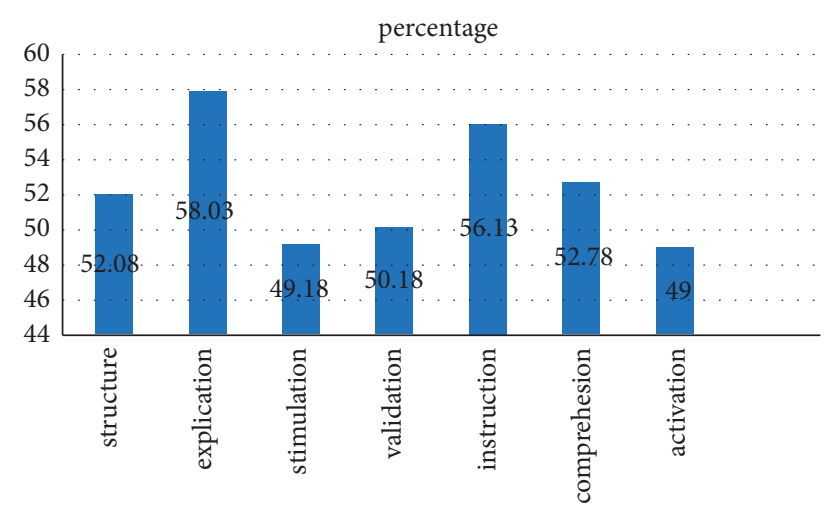

FIGURe 1: Percentage of students' satisfaction using the seven ISQ dimensions.

average satisfaction $(3.54 \pm 0.33)$ as compared to fifth-year students $(3.28 \pm 0.42)(t(103)=3.41, p=0.002)$.

\section{Discussion}

The effectiveness in learning, like all other aspects of human behavior, is highly related to obtaining satisfaction by the learner [12]. Hence, most teaching institutions have carried out a variety of research projects with an increased concern being placed upon students' satisfaction [13]. The issue has gained popularity in recent years, and research findings have established that student ratings can be a reliable and valid indicator of effective teaching $[11,12,14,15]$.

Student satisfaction assessment is vital in determining service quality at academic institutions. To remain competitive, it requires the academic institutions to continuously acquire, maintain, and build stronger relationships with students [10]. Therefore, the study aimed to understand the quality of theory-based pharmacotherapy lectures delivered by their instructors and the clinical pharmacy students' satisfactions towards instructional teaching skills at UoG.

Choosing reliable and quantifiable indicators to assess the quality of one's teaching and the efficiency of teaching initiatives remains challenging. Various student satisfaction tools are employed to assess satisfaction of students on lectures, which are the foundation for future success and final graduation. Of these, we employed the validation tool, ISQ, since it is validated, used by many researchers, and user friendly [11]. Using ISQ, one can provide instructors with immediate, specific, and reliable feedback on their teaching and on differences between student learning outcomes during a course. In addition, researchers can use ISQ to measure differences in efficiency among instructors in academic institutions.

Average satisfaction on each item of ISQ was calculated where the larger the number is, the higher the level of satisfaction on the subject will be. Overall satisfaction on each component was also estimated from the percentage of positive response on each item. For instance, satisfaction was found to be highest about the clarity of the structure of the lecture (mean $\pm \mathrm{SD}=3.49 \pm 1.03$ ), while the overall satisfaction about lecture structure was 52.08\%. However, satisfaction is low with subject matter coherence $($ mean $\pm \mathrm{SD}=2.83 \pm 1.14)$. Since coherence of topics in a course is largely dependent on the structure of the course module, emphasis should be given to course coherence in addition to content during development and revision of curriculums. Thus, subject matter incoherence is common in many institutions and it has a detrimental effect on students' performance in the institution and their future work as well [16-18].

Similarly, regarding explication, "the instructors explain the subject matter clearly" was the most agreed-upon statement (mean $\pm \mathrm{SD}=3.61 \pm 0.98$ ), while the overall satisfaction was $58.03 \%$. The highest and lowest satisfaction levels were recorded with explication (58.03\%) and activation (49\%), respectively. Activation stands for "the extent to which the instructor encourages students to actively think about the subject matter" [11]. This might be due to the training level of the instructors since many of them have learnt using the teacher-centered approach. The activation aspect is more related to the student-centered teaching philosophy and thought to be an emerging philosophy which transforms the performance of academic institutions in view of developing universally competent professionals [19]. This dimension needs to be improved by using different techniques such as introducing small group discussion and peer instruction (also called "Think Pair-Share" or "Concep Tests"), interactive lecture demonstrations (ILDs), case studies, concept mapping, tutorial worksheets, problembased learning, analytical challenge before lecture (also called "invention activities"), problem sets in groups, and random calling in class [19-23]. The study also showed that student satisfaction related to learning outcomes was found to be relatively high (67.23\%).

Student's T-test was performed, and the results showed that extension (night-shift) students have higher average satisfaction score $(3.54 \pm 0.34)$ compared to regular (dayshift) students (mean $\pm \mathrm{SD}=3.31 \pm 0.41, t(103)=2.422$, $p=0.017)$. The higher satisfaction among extension students might be due to the fact that most of the extension students were giving practice to pharmacy technicians who joined the Bachelor of Pharmacy program to advance their professional level. As a result, this group of students are expected to be more familiar to the topics covered in pharmacotherapy courses which could result in more understanding, engagement, and, hence, satisfaction of students from the lectures.

In addition, a higher average satisfaction score was observed among fourth-year students. This may be attributed to the difference in the timing of pharmacotherapy course delivery between fourth-year and fifth-year students relative to the data collection. According to the Nationally Harmonized Modular Curriculum for Bachelor Degree in Pharmacy, pharmacotherapy courses are delivered at the fourth year of the program [24]. Therefore, this study was conducted while the fourth-year students were taking the courses, whereas the fifth-year students had completed the courses in the preceding semesters. Thus, the fact that fourth-year students were acquiring a new set of knowledge from the courses during the study while fifth-year students 
had to reevaluate their satisfaction might have resulted in the higher mean satisfaction score among fourth-year students.

\section{Conclusion}

In conclusion, a higher students' satisfaction was obtained about explication (58.03\%) among seven ISQ dimensions, while students' satisfaction related to activation was minimal (49\%). Students' satisfaction related to the learning outcome was found to be relatively high $(67.23 \%)$. The study also showed that there is a significant difference in students' satisfaction within the different study programs and years of study. Hence, the instructors should work to improve students' satisfaction, thereby increasing the number of qualified professionals in the market.

\section{Abbreviations}

ACCP: American College of Clinical Pharmacy

ISQ: Instructional Skills Questionnaire

UoG: University of Gondar.

\section{Data Availability}

All of the required data will be available upon request to the corresponding author.

\section{Additional Points}

Limitations. (i) The study is conducted in a single institution. (ii) The sample size is small. (iii) One of the co-authors was giving lectures at the study setting and might lead to bias to some extent.

\section{Ethical Approval}

The research was reviewed and approved by the University of Gondar, School of Pharmacy Ethics Review Board with reference number ERB/SoP/057/18.

\section{Consent}

Written informed consent was obtained from each participant.

\section{Conflicts of Interest}

The authors declare no conflicts of interest.

\section{Authors' Contributions}

All authors contributed equally to the reported work, in the concept and design of the research, execution, data collection, analysis, and interpretation and engaged in the drafting and critical review of the paper.

\section{Acknowledgments}

The authors would like to acknowledge the UoG for giving permission to conduct the research.

\section{References}

[1] T. Burki, "From health service to national identity: the NHS at 70," The Lancet, vol. 392, no. 10141, pp. 15-17, 2018.

[2] S. Almagooshi, "Simulation modelling in healthcare: challeng," Procedia Manufacturing, vol. 3, pp. 301-307, 2015.

[3] E. Hadzieva, M. Videnovik, N. Koceska, and V. Trajkovik, "Higher education from a complexity theory perspective," in Proceedings of The Education at the Crossroads-Conditions, Challenges, Solutions and Perspectives, Bitola, Republic of Macedonia, 2018.

[4] R. James, 'Students' changing expectations of higher education and the consequences of mismatches with reality," Responding to student expectations, vol. 1, pp. 71-83, 2002.

[5] G. Sharrock, "Quality in teaching and learning: one path to improvement," Australian Universities Review, vol. 54, no. 2, pp. 78-84, 2012.

[6] K. Devinder and B. Datta, "A study of the effect of perceived lecture quality on post-lecture intentions," Work Study, vol. 52, no. 5, pp. 234-243, 2003.

[7] C. D. Hepler and L. M. Strand, "Opportunities and responsibilities in pharmaceutical care," American Journal of HealthSystem Pharmacy, vol. 47, no. 3, pp. 533-543, 1990.

[8] I. B. Gárate and G. B. Berrotarán, "Self-directed pharmacotherapy learning to fifth-year pharmacy students in Spain," Indian Journal of Pharmaceutical Education and Research, vol. 49, no. 1, pp. 10-17, 2015.

[9] T. L. Charrois and M. Appleton, "Online debates to enhance critical thinking in pharmacotherapy," American Journal of Pharmaceutical Education, vol. 77, no. 8, p. 170, 2013.

[10] L. D. Ried, "A model for curricular quality assessment and improvement," American Journal of Pharmaceutical Education, vol. 75, no. 10, p. 196, 2011.

[11] M. H. Knol, C. V. Dolan, G. J. Mellenbergh, and H. L. J. van der Maas, "Measuring the quality of university lectures: development and validation of the instructional skills questionnaire (ISQ)," PLoS One, vol. 11, no. 2, Article ID e0149163, 2016.

[12] M. T. Tessema, K. Ready, and W. Yu, "Factors affecting college students' satisfaction with major curriculum: evidence from nine years of data," International Journal of Humanities and Social Science, vol. 2, no. 2, pp. 34-44, 2012.

[13] D. E. Clayson, "Student evaluations of teaching: are they related to what students learn?" Journal of Marketing Education, vol. 31, no. 1, pp. 16-30, 2009.

[14] S. Darwin, "The emergence of contesting motives for student feedback-based evaluation in Australian higher education," Higher Education Research and Development, vol. 35, no. 3, pp. 419-432, 2016.

[15] L. Alderman, S. Towers, and S. Bannah, "Student feedback systems in higher education: a focused literature review and environmental scan," Quality in Higher Education, vol. 18, no. 3, pp. 261-280, 2012.

[16] K. Hammerness, "From coherence in theory to coherence in practice," Teachers College Record, vol. 108, no. 7, pp. 1241-1265, 2006.

[17] P. Grossman, K. M. Hammerness, M. McDonald, and M. Ronfeldt, "Constructing coherence," Journal of Teacher Education, vol. 59, no. 4, pp. 273-287, 2008.

[18] J.-C. Smeby and K. Heggen, "Coherence and the development of professional knowledge and skills," Journal of Education and Work, vol. 27, no. 1, pp. 71-91, 2014. 
[19] G. B. Wright, "Student-centered learning in higher education," International Journal of Teaching and Learning in Higher Education, vol. 23, no. 1, pp. 92-97, 2011.

[20] R. Herdlein and E. Zurner, "Student satisfaction, needs, and learning outcomes: a case study approach at a European university," SAGE Open, vol. 5, no. 2, 2015.

[21] S. Suarman, "Teaching quality and students satisfaction: the intermediatory role of relationship between lecturers and students of the higher learning institutes," Mediterranean Journal of Social Sciences, vol. 6, no. 2, 2015.

[22] R. W. Maloy and I. LaRoche, "Student-centered teaching methods in the history classroom: ideas, issues, and insights for new teachers," Social Studies Research \& Practice, vol. 5, no. 2, 2010.

[23] J. A. Lindholm and H. S. Astin, "Spirituality and pedagogy: faculty's spirituality and use of student-centered approaches to undergraduate teaching," The Review of Higher Education, vol. 31, no. 2, pp. 185-207, 2008.

[24] Ministry of Education (MoE), Nationally Harmonized Modular Curriculum for Bachelor Degree in Pharmacy (B.pharm), Ministry of Education (MoE), Addis Ababa, Ethiopia, 2013. 